\title{
Pengaruh Tidak Langsung Employee Training Terhadap Turnover Intention Pada Karyawan Hotel: Peran Workplace Stress Sebagai Mediator
}

\author{
Adrie Oktavio $^{1}$, Agustinus Nugroho ${ }^{2}$, Moses Soediro ${ }^{3}$ \\ 1,2,3 Universitas Ciputra Surabaya \\ e-mail: 1adrie.oktavio@ciputra.ac.id, ${ }^{2}$ agustinus.nugroho@ciputra.ac.id, ${ }^{3}$ msudiro@ciputra.ac.id
}

\begin{abstract}
Abstrak - Tingginya tuntutan pekerjaan di dunia hotel membuat karyawan seringkali mengalami stres yang dapat berujung pada timbulnya niat untuk meninggalkan pekerjaannya saat ini dan mencari pekerjaaan di hotel lain. Tentu saja stres tersebut disebabkan oleh banyak hal yang salah satunya adalah program employee training. Penelitian ini memiliki tujuan untuk menganalisa peran workplace stress sebagai variabel mediasi dari hubungan employee training dan turnover intention pada karyawan hotel berbintang di Surabaya. Metode yang digunakan dalam penelitian ini adalah analisis kuantitatif. Jumlah sampel yang digunakan sebanyak 53 karyawan tetap hotel. Metode yang digunakan adalah non-probability sampling dengan teknik purposive sampling. Teknik pengumpulan data dalam penelitian ini dilakukan dengan membagikan kuesioner yang menggunakan skala Likert. Pengolahan data menggunakan alat analisa GSCA (General Structured Component Analysis). Output yang dihasilkan GSCA yaitu measure of fit pada measurement model (meliputi validity dan reliability), structural model, dan overall model. Berdasarkan hasil analisis data, dapat disimpulkan bahwa employee training tidak berpengaruh signifikan terhadap turnover intention tetapi employee training berpengaruh signifikan positif terhadap workplace stress. Workplace stress berpengaruh signifikan positif terhadap turnover intention. Workplace stress juga mampu berperan sebagai intervening variable yang menjembatani hubungan antara variabel employee training dan variabel turnover intention.
\end{abstract}

Kata Kunci: training; workplace stress; turnover intention; karyawan; hotel

\begin{abstract}
The higher working load at hotel industry sometimes followed by higher stress level of the employees. This phenomenon can lead them to have an intention to resign and looking for another opportunity to apply in another hotel. Stress factor are caused by several problems. One of stress cause can come from employee training program. This study is to analyze the role of workplace stress as a mediating variable of the relationship between employee training and turnover intention in star-rated hotel employee in Surabaya. The research are using quantitative analysis method and using 53 permanent hotel employees as respondents. This research are also using non-probability sampling with purposive sampling technique. Data processing using GSCA (General Structured Component Analysis) analysis tools with likert scale as measurement data collection techniques. The output of data are to measure of fit in the measurement model (including validity and reliability), structural models, and overall models. Based on data analysis, shows that employee training has no significant impact on turnover intention. In other hand, employee training has a significant impact on workplace stress. Workplace stress has a significant impact on turnover intention. And workplace stress are also able to be an intervening variable that relate between employee training variables and turnover intention variables.
\end{abstract}

Keywords: training; workplace stress; turnover intention; employee; hotel

\section{PENDAHULUAN}

Perkembangan bisnis industri perhotelan memiliki kontribusi cukup besar sebagai penunjang perekonomian di Surabaya (Gunawan \& Penangsang, 2017). Hal tersebut ditandai dengan tumbuhnya jumlah hotel yang sangat banyak. Konsekuensi dari banyaknya jumlah hotel bintang yang berdiri di Surabaya membuat tingkat persaingan juga semakin ketat (Desembrianita \& Ruslin, 2016). Pihak manajemen hotel berlomba-lomba menerapkan strategi bisnis yang jitu yang seringkali dikaitkan dengan teknologi terbaru, ataupun menetapkan target yang berat kepada para karyawannya baik itu menyangkut ketepatan waktu pengerjaan tugas maupun kuantitas pekerjaan yang cukup banyak yang harus diselesaikan oleh karyawan. Persaingan yang ketat membuat hotel dituntut untuk selalu dapat memberikan kualitas layanan yang terbaik bagi para tamunya sehingga karyawan juga seringkali dituntut untuk memberikan performa kerja yang tinggi untuk mewujudkan layanan yang berkualitas tersebut (Mmutle \& Shonhe, 2017).

Tingginya tuntutan pekerjaan di dunia hotel membuat karyawan mudah mengalami stres (Lo \& Lamm, 2005). Folkman (2013) menyatakan bahwa 
stres terjadi ketika tuntutan yang ditujukan pada individu dipandang melebihi sumber daya atau kemampuan yang dimiliki oleh individu tersebut. Stres adalah salah satu konsekuensi yang tidak terhindarkan dari tuntutan dunia kerja yang sangat dinamis (Cicchetti, 2010). Lingkungan kerja modern ditandai dengan pengurangan staf, tenggat waktu, persaingan dan perubahan organisasi (Anbazhagan, Rajan, \& Ravichandran, 2013) dan kunci kesuksesan individu untuk beradaptasi pada lingkungan kerja modern tersebut bergantung pada kapasitas individu itu sendiri untuk mengatasi dan bahkan berkembang ketika dihadapkan dengan suasana kerja yang penuh tekanan yang dapat mengakibatkan stres (Bhui, Dinos, Galant-Miecznikowska, de Jongh, \& Stansfeld, 2016). Stres di tempat kerja atau workplace stress secara universal telah menjadi perhatian serius bagi kebanyakan manajer, dan dalam beberapa kelompok kerja, workplace stress telah menjadi epidemi (Lambert, Lambert, \& Yamase, 2003).

Dalam penelitiannya, Keys (1957) membedakan stres menjadi empat jenis yaitu eustress (good stress), distress (bad stress), hyperstress (overstress), dan hypostress (under-stress). Eustress adalah jenis stres yang positif dan diinginkan yang membuat hidup tetap menarik dan membantu memotivasi serta menginspirasi orang. Hal ini menyiratkan bahwa sejumlah stres bermanfaat, dan bahkan baik untuk kesehatan. Ada peningkatan energi dan motivasi yang tinggi sehingga kinerja meningkat secara kuantitatif maupun kualitatif. Distress mengacu pada efek negatif dari stres yang menguras energi seseorang yang melampaui kapasitas kemampuan individu untuk mengatasinya. Hal ini adalah jenis stres dengan tekanan tinggi (high pressure) yang menunjukkan perubahan negatif dalam kinerja secara drastis. Hyperstress artinya terlalu banyak stres yang dialami individu sehingga dapat menyebabkan gangguan fisik dan emosional. Kelebihan beban kerja bisa menjadi sumber umum dari hyperstress. Hypostress mengacu pada sedikitnya kadar stres yang dapat menyebabkan kebosanan, kelesuan, dan frustrasi. Bekerja dengan beban yang terlalu ringan atau bahkan tidak ada pekerjaan sama sekali dapat menyebabkan hypostress dalam beberapa situasi.

Workplace stress yang dibahas dalam penelitian ini termasuk dalam distress yang semestinya segera dicarikan solusinya karena dapat membuat karyawan menderita dan memungkinkan untuk meninggalkan organisasi. Dalam taksonomi stres, workplace stress merupakan sebuah bentuk tekanan yang mana karyawan menjadi terdesak karena tidak memiliki otonomi dan tujuan yang jelas dalam tugas-tugas yang dilakukannya, disertai dengan rasa bosan dan monoton (Mann, 2012).

Untuk memahami dampak workplace stress dengan baik diperlukan kajian atas hasil temuan penelitian terdahulu. Workplace stress dikatakan dapat mengganggu jadwal kerja harian karyawan, menyebabkan kelelahan dan meningkatnya niat untuk berpindah atau meninggalkan organisasi (Javed, Balouch, \& Hassan, 2014). Zhang \& Lee (2010) menjelaskan bahwa workplace stress pada kenyataannya menjadi penyebab utama hilangnya karyawan dari organisasi. Lambert et al. (2003) dalam penelitiannya menyebutkan bahwa workplace stress dapat menimbulkan kerugian yang sangat besar bagi organisasi seperti menurunnya motivasi kerja karyawan, terbuangnya waktu kerja, kehilangan karyawan yang terampil, memaksa organisasi untuk melakukan restrukturisasi proses kerja, serta adanya sabotase, pencurian atau pengrusakan oleh karyawan. Penjelasan yang lebih komprehensif ditemukan pada penelitian Sampson \& Akyeampong (2014) yang membagi efek dari workplace stress ke dalam dua kategori yaitu efek pada individu atau karyawan dan efek pada organisasi. Efek pada individu atau karyawan misalnya gangguan fisik, gangguan emosional, gangguan intelektual dan gangguan pada perilaku atau sikap sehari-hari. Di sisi lainnya, efek workplace stress pada organisasi adalah tingkat absensi yang tinggi, turnover tenaga kerja yang tinggi, kinerja dan produktivitas yang buruk, moral yang rendah, motivasi yang buruk, meningkatnya keluhan karyawan dan meningkatnya gangguan kesehatan, laporan kecelakaan dan insiden dalam pekerjaan.

Dari beberapa hasil temuan terdahulu tersebut, dapat diketahui bahwa salah satu dampak yang dihasilkan oleh workplace stress yaitu dapat mendorong minat individu atau karyawan untuk meninggalkan organisasi atau turnover intention. Padahal dalam situasi persaingan yang demikian ketat, hotel harus mampu untuk memelihara dengan sebaik mungkin sumber daya yang dimilikinya termasuk karyawan (Fraj, Matute, \& Melero, 2015). Karyawan sebagai salah satu kunci kesuksesan perusahaan perlu dikelola dengan baik agar tetap loyal di tempat kerjanya (Goffee \& Jones, 2013). Beberapa pimpinan organisasi yang memiliki pemikiran modern bahkan menyatakan bahwa retensi karyawan yang telah berkontribusi positif bagi organisasi jauh lebih penting dibandingkan sekedar mempertahankan keunggulan kompetitif (Skelton, Nattress, \& Dwyer, 2019).

Saeed, Waseem, Sikander, \& Rizwan (2014) menjelaskan bahwa turnover intention adalah keinginan karyawan yang secara sukarela berniat untuk meninggalkan perusahaan atau berhenti dari tempat kerja. Konsekuensinya bagi perusahaan adalah hilangnya biaya yang telah dikeluarkan untuk proses perekrutan dan pelatihan (Mamun \& Hasan, 2017) dan tentu saja perusahaan harus mengeluarkan biaya lagi untuk merekrut pengganti karyawan yang berhenti tadi. Guilding, Lamminmaki, \& McManus (2014) menjelaskan secara lebih rinci bahwa tingkat turnover yang tinggi berdampak negatif dan merugikan perusahaan seperti munculnya separation cost, replacement cost, training cost, dan vacancy 
cost. Separation cost meliputi biaya wawancara saat exit interview dan biaya pemberhentian dan pelepasan karyawan. Replacement cost merupakan biaya-biaya yang dikeluarkan perusahaan untuk proses perekrutan pengganti karyawan yang telah resign seperti biaya iklan lowongan kerja, biaya wawancara dan seleksi. Training cost meliputi biaya formal training maupun informal training bagi karyawan baru. Vacancy cost merupakan biaya yang dikeluarkan perusahaan ketika terjadi kekosongan posisi atau jabatan sehingga perusahaan harus mencari karyawan pengganti untuk mengisi posisi atau jabatan yang lowong tadi.

Melihat dampak yang begitu serius dari turnover karyawan membuat pihak manajemen hotel harus lebih jeli untuk memonitor para karyawan (Radianto \& Wijaya, 2020) apabila ada karyawan yang mulai merasa tertekan dengan pekerjaan atau lingkungan kerjanya. Perasaan tertekan inilah yang lama-lama bisa membuat karyawan menjadi stres dan lebih dari itu dapat menjadi sinyal awal untuk berhenti bekerja atau meninggalkan perusahaan (Sewwandi \& Perere, 2016) karena turnover intention adalah sinyal awal dari employee turnover karyawan di dalam perusahaan (Khalida \& Safitri, 2018).

Hotel perlu mencermati faktor-faktor yang menyebabkan stres pada karyawan atau biasa disebut stressor (Sampson \& Akyeampong, 2014). Salah satu faktor penyebab workplace stress yang dibahas dalam penelitian ini adalah program pelatihan karyawan atau training yang diadakan oleh pihak manajemen hotel. Secara umum, dapat dikatakan bahwa training dapat mempengaruhi workplace stress. Beberapa penelitian sebelumnya sebagian besar menyimpulkan bahwa training memberikan pengaruh negatif terhadap workplace stress. Meskipun belum ada kesepakatan secara global tentang definisi stres, namun sering kali hal itu dipandang sebagai perubahan keadaan yang menyebabkan seseorang menghadapi tekanan atau tuntutan yang mengganggu mereka (Schuler, 1980) dan dianggap sangat beresiko (Xie, Wang, \& Chen, 2011). Workplace stress dapat terjadi ketika karyawan tidak diberikan training atau sumber daya yang memadai untuk mendukung pekerjaan mereka (Ertan \& Şeşen, 2019). Karasek (1979) menerangkan dalam artikelnya bahwa individu yang memiliki tuntutan pekerjaan yang tinggi dan kontrol yang rendah akan mengalami tingkat stres yang tinggi. Tuntutan pekerjaan yang tinggi dan rendahnya kontrol dianggap sebagai pekerjaan berat (high-strain jobs) (Karasek \& Theorell, 1990), dan kurangnya training atau pengalaman dapat memperburuk kontrol yang rendah (Verhofstadt, Baillien, Verhaest, \& De Witte, 2017). Beberapa penelitian melaporkan tren yang mengkhawatirkan dalam pengaturan layanan jasa di perhotelan yaitu buruknya organisasi kerja (cara mendesain pekerjaan dan sistem kerja, dan cara mengelolanya), desain kerja yang buruk (misalnya, kurangnya kontrol atas proses kerja), manajemen yang buruk, kondisi kerja yang tidak memuaskan, dan kurangnya dukungan dari rekan kerja dan pimpinan (Sampson \& Akyeampong, 2014). Tren tersebut dapat dikaitkan dengan kurang tercukupinya sumber daya pekerjaan (misalnya kurangnya training). Dengan kata lain, ketidaksesuaian antara tuntutan pekerjaan dan alokasi sumber daya dapat meningkatkan stres karena karyawan yang tidak memenuhi syarat atau tidak siap untuk menyediakan layanan yang efisien dan berkualitas tinggi.

Data empiris dari berbagai penelitian juga menunjukkan bahwa peningkatan sumber daya kerja melalui investasi training dapat mengurangi niat pergantian karyawan (Bulut \& Culha, 2010; Long, Ajagbe, \& Kowang, 2014; Schaufeli \& Bakker, 2004). Batt (2002) juga mengemukakan bahwa praktek-praktek organisasi yang membutuhkan keterlibatan karyawan seperti training akan berpengaruh terhadap penurunan turnover intention karyawan dan peningkatan produktivitas. Turnover intention adalah kecenderungan karyawan untuk memiliki kinerja yang buruk yang disengaja dengan tujuan untuk berhenti dari pekerjaan (Harrell-Cook, Appelbaum, Bailey, Berg, \& Kalleberg, 2001). Hal ini karena adanya kesenjangan antara keterampilan yang diperlukan dan tuntutan penyelesaian pekerjaan yang tinggi sehingga membuat kepuasan kerja menurun yang pada akhirnya terjadi pergantian karyawan (Memon, Salleh, \& Baharom, 2016; Truitt, 2011).

Berdasarkan pemaparan di atas, penelitian ini mencoba untuk menganalisa apakah workplace stress mampu memediasi hubungan antara training dan turnover intention pada karyawan hotel atau justru training dapat secara langsung mempengaruhi turnover intention tanpa peran dari workplace stress seperti yang nampak pada Gambar 1 .

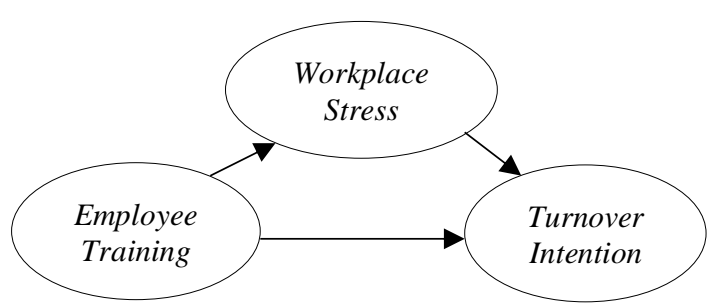

Gambar 1. Model Penelitian

Adapun hipotesis penelitian yang dapat dirumuskan dari gambar model penelitian di atas adalah employee training berpengaruh terhadap turnover intention (hipotesis 1); employee training berpengaruh terhadap workplace stress (hipotesis 2); workplace stress berpengaruh terhadap turnover intention (hipotesis 3); dan workplace stress memediasi hubungan antara employee training dan turnover intention (hipotesis 4). 


\section{METODE PENELITIAN}

Penelitian ini merupakan penelitian kuantitatif yang menggunakan Structural Equation Modeling (SEM) dalam menganalisa model penelitian yang diusulkan serta untuk mengidentifikasi pengaruh dari dua variabel atau lebih (Zikmund, Babin, Carr, \& Griffin, 2013). Sampel yang digunakan dalam penelitian ini adalah karyawan hotel berbintang di kota Surabaya. Purposive sampling dipilih oleh peneliti sebagai teknik pengambilan sampel dimana pengambilan sampel dilakukan secara proporsional dan atas dasar pertimbangan tertentu (Etikan, 2016; Tongco, 2007) yaitu kesediaan dari pihak hotel yang mengijinkan karyawannya dijadikan sampel dan cakupan area penyebaran hotel yang begitu luas di Surabaya.

Pengumpulan data penelitian dilakukan pada bulan Januari-Februari 2020 dengan cara menyebarkan kuesioner kepada para karyawan tetap hotel yang sudah bekerja minimal satu tahun yang tersebar di 19 hotel bintang yang meliputi 10 hotel bintang tiga, 4 hotel bintang empat dan 5 hotel bintang lima.

Masing-masing hotel menerima 4 kuesioner sehingga total jumlah kuesioner yang disebar sebanyak 76 kuesioner. Pemilihan karyawan yang dipercaya untuk mengisi kuesioner tersebut merupakan kewenangan dari masing-masing pihak manajemen hotel. Dari hasil penyebaran kuesioner tersebut, peneliti berhasil mengumpulkan 53 kuesioner $(69,7 \%)$ yang terisi lengkap dan layak untuk diolah datanya.

Data penelitian diolah menggunakan alat analisa General Structured Component Analysis (GSCA) yang dikembangkan oleh Hwang \& Takane (2014) yang sudah cukup banyak digunakan oleh para peneliti. Output yang dihasilkan dari pengolahan data menggunakan GSCA adalah measure of fit (validitas dan reliabilitas) pada measurement model, structural model, dan overall model.

Keseluruhan indikator untuk mengukur variabel-variabel penelitian ini diambil dari beberapa penelitian terdahulu dengan mempertimbangkan nilai validitas tertinggi dalam penelitian yang diadopsi tersebut. Empat indikator pengukur variabel employee training diadaptasi dari penelitian Bulut \& Culha (2010). Variabel workplace stress diukur dengan lima indikator dari penelitian Sewwandi \& Perere (2016). Variabel terikat penelitian ini yaitu turnover intention menggunakan 4 indikator penelitian Memon, Salleh, \& Baharom (2016).

\section{HASIL DAN PEMBAHASAN}

\section{Karakteristik Responden}

Profil responden yang berpartisipasi dalam penelitian ini sebanyak 31 responden $(58,5 \%)$ berjenis kelamin wanita, dan sisanya sebesar 22 responden $(41,5 \%)$ adalah pria. Dari faktor usia, paling banyak adalah responden yang berusia 26-33 tahun sebanyak
27 responden $(50,9 \%)$ disusul 11 responden $(20,8 \%)$ dari golongan usia 34-41 tahun; 10 responden $(18,9 \%)$ berusia 18-25 tahun; dan sisanya 5 responden $(9,4 \%)$ berusia di atas 42 tahun. Selanjutnya dari faktor keragaman departemen dimana karyawan ditempatkan diketahui bahwa 16 responden $(30,2 \%)$ berasal dari sales \& marketing department; 10 responden $(18,9 \%)$ bekerja di front office department; 8 responden $(15,1 \%)$ dari accounting department; 7 responden $(13,2 \%)$ dari $F \& B$ department; 5 responden $(9,4 \%)$ bekerja di $H R$ department; 3 responden $(5,7 \%)$ di security department; dan masing-masing 2 responden $(3,8 \%)$ bekerja di engineering department dan housekeeping department.

\section{Validitas dan Reliabilitas}

Hasil uji validitas dan reliabilitas yang disajikan pada Tabel 1 menunjukkan bahwa keseluruhan indikator dinyatakan valid dan reliabel. Nilai Cronbach's Alpha dan Dillon-Goldstein's Rho digunakan untuk memeriksa internal consistency indikator untuk setiap variabel laten. Dengan kata lain nilai Cronbach's Alpha dan Dillon-Goldstein's Rho merupakan patokan composite reliability dimana syaratnya adalah $>0,7$. Sedangkan untuk pengukuran convergent validity variabel laten menggunakan nilai AVE (Average Variance Extracted) dengan nilai minimum yang dipersyaratkan sebesar $>0,5$.

Tabel 1. Hasil Pengujian Validatias dan Reliabilitas

\begin{tabular}{|l|c|c|c|}
\hline Variabel & $\begin{array}{c}\text { Cronbach's } \\
\text { Alpha }\end{array}$ & $\begin{array}{c}\text { Dillon- } \\
\text { Goldstein's } \\
\text { rho }\end{array}$ & AVE \\
\hline $\begin{array}{l}\text { Employee } \\
\text { Training }\end{array}$ & 0,7677 & 0,8521 & 0,5915 \\
\hline $\begin{array}{l}\text { Workplace } \\
\text { Stress }\end{array}$ & 0,7864 & 0,8535 & 0,5409 \\
\hline $\begin{array}{l}\text { Turnover } \\
\text { Intention }\end{array}$ & 0,7956 & 0,8583 & 0,5493 \\
\hline
\end{tabular}

Sumber: Olah Data GSCA (2020)

\section{Goodness of Fit}

Tabel 2 merupakan hasil pengujian goodness of fit yang diinterpretasikan dari nilai FIT, AFIT (Adjusted FIT), GFI (Goodness-of-Fit Index) dan SRMR (Standardized Root Mean Square Residual).

Tabel 2. Uji Goodness of Fit

\begin{tabular}{|l|c|}
\hline \multicolumn{1}{|c|}{ Model Fit } & Measure \\
\hline FIT & 0,5749 \\
\hline AFIT (Adjusted Fit) & 0,5564 \\
\hline GFI (Goodness of Fit Index) & 0,9916 \\
\hline SRMR (Standardized Root Mean Square) & 0,0989 \\
\hline
\end{tabular}

Sumber: Olah Data GSCA (2020)

Diketahui bahwa nilai FIT sebesar 0,5799 sehingga dapat diinterpretasikan bahwa model penelitian sudah cukup baik dalam menjelaskan 
fenomena yang diteliti. Nilai FIT (berkisar dari nilai 0 hingga 1) memberikan penjelasan tentang total varian dari keseluruhan variabel yang dapat dijelaskan oleh model tertentu (Hwang, Takane, \& Jung, 2017). Variabel employee training dan workplace stress mampu mempengaruhi turnover intention sebesar $57,99 \%$ dan 42,01 sisanya akan dijelaskan oleh variabel lainnya di luar model.

Pada Tabel 2 diketahui bahwa nilai AFIT lebih rendah dari nilai FIT karena AFIT lebih kompleks dalam mengukur model sedangkan FIT lebih sensitif terhadap komplesitas model. Oleh karena itu AFIT lebih disarankan untuk digunakan dalam menginterpretasikan ketepatan model dan sebagai dasar dalam melakukan perbandingan model. Hal ini dikarenakan turnover intention dipengaruhi lebih dari satu variabel. AFIT yang bernilai 0,5564 diartikan bahwa keragaman variabel employee training, workplace stress dan turnover intention adalah sebesar $55,64 \%$, sedangkan $44,36 \%$ sisanya dapat dijelaskan oleh variabel yang lain di luar model penelitian.

Nilai GFI dapat diinterpretasikan sebagai tingkat relevansi antara fakta yang diteliti dan teori yang digunakan seperti yang tergambar dalam model penelitian. Model penelitian diasumsikan dapat menggambarkan tingkat relevansi yang kuat jika nilai $G F I>90 \%$. Dari hasil olah data didapatkan nilai GFI sebesar 0,9916 atau 99,16\%. Artinya model penelitian dapat diterima dan menggambarkan relevansi yang kuat antara teori dan fenomena penelitian.

Nilai SRMR menunjukkan tingkat fit model. Apabila nilainya semakin kecil (mendekati nilai 0) berarti model dikatakan semakin baik. Nilai SRMR sebesar 0.0989, sehingga dapat dinyatakan bahwa model penelitian adalah acceptable fit atau sudah cukup baik.

\section{Uji Hipotesis}

Hasil uji hipotesis pada pengaruh langsung antara variabel employee training, workplace stress dan turnover intention yang disajikan pada Tabel 3 diketahui bahwa hanya hipotesis kedua dan ketiga saja yang diterima karena nilai $C R$ (Critical Ratio) > +/1,96. Perhitungan nilai $C R$ diperoleh dari hasil pembagian nilai estimate dengan nilai SE (Standard Error).

Tabel 3. Hasil Uji Hipotesis

\begin{tabular}{|l|c|c|c|l|}
\hline Hipotesis & Estimate & $S E$ & $C R$ & Ket. \\
\hline $\mathrm{ET} \rightarrow$ TI & $-0,0793$ & 0,0735 & $-1,079$ & Ditolak \\
\hline $\begin{array}{l}\text { ET } \rightarrow \\
\text { WS }\end{array}$ & 0,5034 & 0,0594 & 8,475 & Diterima \\
\hline WS $\rightarrow$ TI & 0,5146 & 0,0753 & 6,834 & Diterima \\
\hline
\end{tabular}

Sumber: Olah Data GSCA (2020)

Hasil uji hipotesis pertama menunjukkan bahwa nilai estimate sebesar $-0,0793$ dan nilai $C R$ sebesar -1,079 $(<-1,96)$ sehingga employee training berpengaruh negatif namun tidak signifikan terhadap turnover intention secara lansung. Hasil uji hipotesis kedua yang menyangkut pengaruh langsung antara employee training terhadap workplace stress dinyatakan signifikan dengan nilai $C R$ sebesar 8.475 (> 1.96) dan nilai estimate bernilai 0,5034 yang menunjukkan bahwa arah hubungan antara employee training terhadap workplace stress adalah positif. Selanjutnya pada uji hipotesis yang ketiga terkait pengaruh langsung antara workplace stress terhadap turnover intention menunjukkan pengaruh positif dan signifikan karena nilai estimate sebesar 0,5146 dan CR sebesar 6,834 (> 1.96), sehingga hipotesis ketiga diterima.

Untuk hipotesis keempat terkait peran workplace stress sebagai intervening variable yang memediasi pengaruh employee training terhadap turnover intention, maka teori Baron \& Kenny (1986) tentang mediasi digunakan sebagai dasarnya. Baron \& Kenny (1986) menyatakan bahwa syarat utama untuk melakukan uji mediasi adalah adanya pengaruh signifikan dari variabel independen ke intervening variabel dan ada pengaruh yang signifikan pula dari intervening variabel ke varibel dependen. Bila salah satu syarat tersebut tidak terpenuhi, maka tidak perlu dilakukan uji mediasi. Dengan demikian, hipotesis keempat yang diajukan dalam penelitian ini dinyatakan diterima karena workplace stress mampu memediasi pengaruh antara variabel employee training dan turnover intention dan sifatnya mediasi sempurna (full mediation).

\section{Employee Training Berpengaruh Negatif Namun Tidak Signifikan Terhadap Turnover Intention}

Temuan penelitian ini tidak sejalan dengan banyak hasil penelitian sebelumnya seperti Memon et al. (2016), Huang \& Su (2016) dan Ertan \& Şeşen (2019). Secara arah hubungan, employee training berpengaruh negatif terhadap turnover intention namun pengaruhnya tidak siginifikan.

Penelitian Aragón-Sánchez, Barba-Aragáon, \& Sanz-Valle (2003) dapat dijadikan jawaban logis dan ilmiah atas temuan ini. Aragón-Sánchez et al. (2003) berargumen bahwa program training yang diberikan oleh organisasi kepada karyawan dapat memberikan dampak yang berbeda tergantung pada kondisi yang dirasakan oleh karyawan itu sendiri. Salah satu kondisi yang dimaksud adalah persepsi karyawan terhadap tujuan dan manfaat dari diberikannya program training. Maksudnya, karyawan mempersepsikan bahwa program training yang diberikan organisasi kurang begitu bermanfaat karena tidak sesuai dengan tujuan awal diselenggarakannnya program training tersebut.

Untuk mengkonfirmasi sekaligus memperkuat argumentasi dari Aragón-Sánchez et al. (2003) tersebut maka peneliti melakukan wawancara singkat melalui sambungan telepon terhadap tiga karyawan yang menjadi responden penelitian ini. Ketiga karyawan 
tersebut dipilih secara acak dan berasal dari hotel yang berbeda. Dari hasil wawancara singkat tersebut diketahui fakta bahwa selama ini cukup banyak program training yang diberikan oleh pihak manajemen hotel yang kurang bermanfaat di mata karyawan. Sebagai contoh sebuah program training pada awalnya diberikan sebagai sarana knowledge transfer bagi karyawan. Namun pada realitanya program training tersebut kurang dapat memberikan pengetahuan baru di mata karyawan dan hal tersebut seringkali terjadi.

Bila kondisi semacam ini dibiarkan terusmenerus dan tidak segera dilakukan langkah-langkah evaluasi dan perbaikan yang tepat, maka maka minat karyawan bisa menjadi semakin menurun dan malas untuk mengikuti program-program training selanjutnya.

\section{Employee Training Berpengaruh Positif dan Signifikan Terhadap Workplace Stress}

Dari hasil analisa statistik sebelumnya pada Tabel 3 diketahui bahwa employee training memang berpengaruh terhadap workplace stress. Namun yang membedakan dengan hasil temuan penelitianpenelitian sebelumnya yaitu pengaruhnya memiliki arah hubungan positif. Artinya, bila program training semakin banyak diberikan kepada karyawan hotel maka justru dapat membuat karyawan menjadi stres. Padahal kebanyakan penelitian yang sudah ada menyatakan bahwa arah hubungan antara employee training terhadap workplace stress adalah negatif (Ertan \& Şeşen, 2019; Sampson \& Akyeampong, 2014) yang artinya semakin banyak program training yang didapatkan karyawan justru dapat menurunkan stress karyawan.

Penjelasan atas hasil temuan ini mugkin dapat mengacu kembali dari hasil penelitian AragónSánchez, Barba-Aragáon, \& Sanz-Valle (2003). Menurut Aragón-Sánchez et al. (2003), ketika program training berubah menjadi lebih intensif dan memerlukan daya upaya karyawan yang lebih besar, maka karyawan malah menjadi tertekan. Peningkatan jumlah jam dalam training juga akan membuat karyawan merasa terganggu karena dapat menghambat karyawan untuk menyelesaikan berbagai macam pekerjaannya yang cukup banyak.

Dari gambaran kondisi tersebut, maka pada akhirnya karyawan mempersepsikan training hanyalah sebagai beban kerja yang memberatkan dan menambah volume pekerjaan bagi karyawan. Training dianggap sebagai sebuah bentuk tuntutan yang dapat mengganggu karyawan hotel. Ketika karyawan selesai mengikuti training, maka karyawan sudah diperhadapkan pada pekerjaan yang terbengkelai atau tertunda sebelumnya.

Oleh karena itu, apabila persepsi negatif karyawan tentang training tersebut dibiarkan begitu saja dalam waktu yang lama maka tentu saja akan memicu rasa stres dalam diri karyawan. Terlebih bagi hotel yang tidak terlalu besar dan jumlah sumber daya manusianya terbatas, training yang berlebihan (baik dari faktor waktu maupun intensitas) dapat menjadi beban yang memberatkan karyawan.

\section{Workplace Stress Berpengaruh Positif dan Signifikan Terhadap Turnover Intention}

Diterimanya hipotesis ketiga penelitian ini semakin mempertegas hasil-hasil penelitian Zhang \& Lee (2010) dan Javed et al. (2014). Semakin tinggi tingkat workplace stress yang dialami karyawan akan memperbesar potensi tingginya tingkat turnover intention tidak terkecuali bagi para karyawan hotel. Selain turnover, workplace stress memiliki dampak buruk pada produktifitas, kesehatan dan kesejahteraan karyawan (Sampson \& Akyeampong, 2014; Vagg \& Spielberger, 1998). Workplace stress memiliki konsekuensi yang cenderung tidak diinginkan yaitu dapat melemahkan individu dan organisasi serta biaya yang mahal (Ross, 2006).

Workplace stress yang meningkat biasanya ditandai sebuah tekanan seperti beban kerja yang berlebih dan konflik peran yang dirasakan oleh karyawan (Sampson \& Akyeampong, 2014). Karyawan mengalami tekanan yang secara perlahan atau cepat akan menimbulkan menimbulkan kecemasan atau stres. Bila stres tersebut tidak dikelola dengan baik maka dapat menimbulkan turnover intention. Karyawan yang bekerja di industri perhotelan biasanya mengalami tingkat stres yang tergolong tinggi khususnya karyawan yang bekerja di bagian operasional hotel. Mereka umumnya bekerja dalam system shift karena hotel beroperasi selama 24 jam. Sekalipun ada karyawan yang tidak mengalami pembagian shift kerja, namun tingkat beban kerja yang diterima juga sangat padat. Biasanya karyawan hotel dituntut untuk mampu mengerjakan banyak hal tidak seperti karyawan di bidang industri lainnya.

\section{Workplace Stress Sebagai Variabel Intervening}

Hasil penelitian ini menunjukkan bahwa turnover intention bukan dipicu secara langsung oleh employee training tetapi ada faktor pemicu lainnya yaitu workplace stress. Temuan ini selaras dengan hasil penelitian milik Ertan \& Şeşen (2019).

Ketika karyawan merasa bahwa program training yang harus diikutinya dipersepsikan negatif sebagai suatu aktivitas yang justru dapat menambah beban kerja dan hanya membuang waktu karyawan maka karyawan berpotensi mengalami stres. Dan bila kondisi semacam ini berlangsung berulang kali maka dapat memicu minat karyawan untuk mencari pekerjaan di tempat lain.

Pengembangan diri karyawan dalam bentuk training merupakan suatu hal yang sangat penting. Akan tetapi besar kecilnya biaya yang dikeluarkan untuk melakukan program training belum tentu berpengaruh terhadap keberhasilan sebuah perusahaan termasuk hotel dalam melakukan pengembangan 
terhadap karyawannya. Hal yang menentukan sebenarnya adalah tingkat efektifitas dari proses training tersebut. Dalam proses training, pihak manajemen disarankan untuk tetap berpedoman pada rancangan yang telah dibuat sebelumnya dan juga wajib mengedepankan fleksibilitas ketika terjadi hambatan. Pihak manajemen juga harus melakukan pengamatan, penilaian dan evaluasi secara kritis dan mendalam terhadap sebuah proses training agar bisa maksimal.

Perhatian secara khusus dalam implementasi dan penyampaian training pada karyawan disertai dengan proses yang fleksibel dimaksudkan agar training tersebut dapat memberikan makna dan manfaat yang besar bagi karyawan yang mengikuti training tersebut sehingga karyawan memiliki persepsi yang positif atas pelaksanaan training tersebut. Jika proses training tidak dijalankan secara tepat dan efektif, perusahaan akan mengalami kerugian secara finansial dan mendapatkan dampak negatif dalam jangka panjang. Dampak negatif yang dimaksud dapat berupa menurunnya minat karyawan hotel terhadap training diikutinya karena hanya dipersepsikan sebagai beban kerja yang memberatkan karyawan. Akumulasi dari menurunnya minat karyawan tersebut dalam jangka waktu yang lama dapat membuat karyawan kehilangan keterikatan dengan perusahaan dan pada akhirnya menimbulkan niat untuk meninggalkan perusahaan.

\section{KESIMPULAN}

Lingkungan kerja di industri hotel merupakan lingkungan yang sangat dinamis karena sifatnya yang memberikan pelayanan kepada tamu selama 24 jam. Sehingga tuntutan pekerjaan yang harus diselesaikan oleh karyawan hotel juga sangat tinggi. Tingginya tuntutan kerja tersebut pada akhirnya menjadi tekanan pekerjaan yang harus dipikul oleh karyawan. Permasalahannya adalah tidak semua karyawan memiliki daya tahan yang sama dalam mengatasi tekanan pekerjaan tersebut. Seringkali karyawan hotel mengalami perasaan tertekan yang berlebihan akibat beban pekerjaan yang dirasakan terlalu berat. Perasaan tertekan inilah yang membuat karyawan akhirnya menjadi stres. Rasa stres ini bila tidak segera dicarikan jalan keluarnya akan membuat karyawan menjadi semakin tidak nyaman dan beresiko berhenti dari pekerjaannya. Stressor atau penyebab stres di tempat kerja salah satunya berasal lingkungan internal hotel sendiri yaitu adanya program training bagi karyawan.

Penelitian ini menganalisa bagaimana workplace stres yang disebabkan oleh adanya employee training berpengaruh terhada turnover intention pada karyawan hotel di Surabaya. Hasil penelitian menunjukkan bahwa employee training berpengaruh terhadap workplace stress namun tidak berpengaruh langsung terhadap turnover intention. Workplace stress juga berpengaruh terhadap turnover intention serta mampu berperan sebagai mediator pengaruh antara employee training dan turnover intention.

Penelitian ini juga memberikan celah bagi penelitian selanjutnya perlunya mengidentifikasi jenis training secara spesifik sehingga hasilnya bisa lebih valid dan tidak menimbulkan bias khususnya untuk melihat pengaruhnya terhadap workplace stress dan turnover intention karyawan hotel. Selain jenis training, mungkin juga lebih dispesifikkan pada jumlah jam dan frekuensi training sehingga bisa diketahui secara lebih mendalam tentang bagaimana intensitas dari masing-masing karyawan terhadap program training yang telah diikutinya.

\section{REFERENSI}

Anbazhagan, A., Rajan, L. J. S., \& Ravichandran, A. (2013). Work stress of hotel industry employees in Puducherry. Asia-Pacific Journal of Business Administration, 2(5), 85-101.

Aragón-Sánchez, A., Barba-Aragáon, I., \& SanzValle, R. (2003). Effects of training on business results. International Journal of Human Resource Management, 14(6), 956-980. https://doi.org/10.1080/095851903200010616 4

Baron, R. M., \& Kenny, D. A. (1986). The moderatormediator variable distinction in social psychological research: Conceptual, strategic, and statistical considerations. Journal of Personality and Social Psychology, 51(6), 1173-1182. https://doi.org/10.1037/00223514.51.6.1173

Batt, R. (2002). Managing customer services: Human resource practices, quit rates, and sales growth. Academy of Management Journal, 45(3), 587597. https://doi.org/10.2307/3069383

Bhui, K., Dinos, S., Galant-Miecznikowska, M., de Jongh, B., \& Stansfeld, S. (2016). Perceptions of work stress causes and effective interventions in employees working in public, private and non-governmental organisations: a qualitative study. BJPsych Bulletin, 40(6), 318325. https://doi.org/10.1192/pb.bp.115.050823

Bulut, C., \& Culha, O. (2010). The effects of organizational training on organizational commitment. International Journal of Training and Development, 14(4), 309-322. https://doi.org/10.1111/j.14682419.2010.00360.x

Cicchetti, D. (2010). Resilience under conditions of extreme stress: A multilevel perspective. World Psychiatry, 9(3), 145-154. https://doi.org/10.1002/j.2051- 
5545.2010.tb00297.x

Desembrianita, E., \& Ruslin, R. (2016). Pengaruh kualitas pelayanan, fasilitas dan harga terhadap keputusan pelanggan untuk menggunakan jasa Hotel Oval Surabaya. Jurnal Riset Ekonomi Dan Manajemen, 16(2), 345. https://doi.org/10.17970/jrem.16.1602013.id

Ertan, A. S., \& Şeşen, H. (2019). Positive organizational scholarship in healthcare: The impact of employee training on performance, turnover, and stress. Journal of Management and Organization, August https://doi.org/10.1017/jmo.2019.61

Etikan, I. (2016). Comparison of convenience sampling and purposive sampling. American Journal of Theoretical and Applied Statistics, $5(1)$, https://doi.org/10.11648/j.ajtas.20160501.11

Folkman, S. (2013). Stress: Appraisal and coping. In Encyclopedia of Behavioral Medicine (pp. 1913-1915). https://doi.org/10.1007/978-14419-1005-9_215

Fraj, E., Matute, J., \& Melero, I. (2015). Environmental strategies and organizational competitiveness in the hotel industry: The role of learning and innovation as determinants of environmental success. Tourism Management, 46 , $30-42$. https://doi.org/10.1016/j.tourman.2014.05.009

Goffee, R., \& Jones, G. (2013). Creating the best workplace on earth. Harvard Business Review, 91(5).

Guilding, C., Lamminmaki, D., \& McManus, L. (2014). Staff turnover costs: In search of accountability. International Journal of Hospitality Management, 36, 231-243. https://doi.org/10.1016/j.ijhm.2013.10.001

Gunawan, \& Penangsang, P. (2017). Analisis pengaruh sektor perdagangan, hotel, dan restoran terhadap pertumbuhan ekonomi (Studi kasus pada Kota Surabaya). Jurnal Ekonomi \& Bisnis, 2(1), 317-334.

Harrell-Cook, G., Appelbaum, E., Bailey, T., Berg, P., \& Kalleberg, A. L. (2001). Manufacturing advantage: Why high-performance work systems pay off. The Academy of Management Review, 26(3), 459 https://doi.org/10.2307/259189

Huang, W. R., \& Su, C. H. (2016). The mediating role of job satisfaction in the relationship between job training satisfaction and turnover intentions. Industrial and Commercial Training, 48(1), 42-52. https://doi.org/10.1108/ICT-04-2015-0029

Hwang, H., \& Takane, Y. (2014). Generalized structured component analysis: A componentbased approach to structural equation modeling. Generalized Structured Component Analysis: A Component-Based Approach to Structural Equation Modeling. https://doi.org/10.1201/b17872

Hwang, H., Takane, Y., \& Jung, K. (2017). Generalized structured component analysis with uniqueness terms for accommodating measurement error. Frontiers in Psychology, 8 (DEC). https://doi.org/10.3389/fpsyg.2017.02137

Javed, M., Balouch, R., \& Hassan, F. (2014). Determinants of job satisfaction and its impact on employee performance and turnover intentions. International Journal of Learning and Development, 4(2). https://doi.org/10.5296/ijld.v4i2.6094

Karasek, R. (1979). Job demands, job decision latitude, and mental strain: Implications for job redesign. Administrative Science Quarterly, 24(2), 285. https://doi.org/10.2307/2392498

Karasek, R., \& Theorell, T. (1990). Healthy work: Stress, productivity, and the reconstruction of working life (1st ed.). New York: Basic Books.

Keys, A. (1957). The stress of life. American Journal of Public Health and the Nations Health, 47(5), 624-625. https://doi.org/10.2105/ajph.47.5.624

Khalida, R., \& Safitri, N. (2018). The effect of person-organization fit on turnover intention with job satisfaction as mediating variable. Bisnis \& Birokrasi Journal, 23(3). https://doi.org/10.20476/jbb.v23i3.9173

Lambert, V. A., Lambert, C. E., \& Yamase, H. (2003). Psychological hardiness, workplace stress and related stress reduction strategies. Nursing and Health Sciences. https://doi.org/10.1046/j.14422018.2003.00150.x

Lo, K., \& Lamm, F. (2005). Occupational stress in the hospitality industry - An employment relations perspective. New Zealand Journal of Employment Relations, 30(1), 23. Retrieved from

https://login.libproxy.edmc.edu/login?url=http ://origin-

search.proquest.com/docview/213507533?acc ountid=34899\%5Cnhttp://resolver.ebscohost.c om/openurl?ctx_ver=Z39.88-

2004\&ctx_enc=info:ofi/enc:UTF-

8\&rfr_id=info:sid/ProQ\%3Aabiglobal\&rft_val _fmt=info:ofi/fmt

Long, C. S., Ajagbe, M. A., \& Kowang, T. O. (2014). Addressing the issues on employees' turnover intention in the perspective of HRM practices in SME. Procedia - Social and Behavioral Sciences, 129, 99-104. https://doi.org/10.1016/j.sbspro.2014.03.653

Mamun, C. A. Al, \& Hasan, M. N. (2017). Factors 
affecting employee turnover and sound retention strategies in business organization: A conceptual view. Problems and Perspectives in Management, $\quad$ 15(1), 63-71. https://doi.org/10.21511/ppm.15(1).2017.06

Mann, S. (2012). Boredom at the checkout causes , coping strategies and outcomes of workplace boredom in a supermarket setting. Journal of Business and Retail Management Research, 6(April), 1-14.

Memon, M. A., Salleh, R., \& Baharom, M. N. R. (2016). The link between training satisfaction, work engagement and turnover intention. European Journal of Training and Development, 40(6), 407-429. https://doi.org/10.1108/EJTD-10-2015-0077

Mmutle, T., \& Shonhe, L. (2017). Customers' perception of service quality and its impact on reputation in the hospitality industry. African Journal of Hospitality, Tourism and Leisure, 6(3).

Radianto, W. E. D., \& Wijaya, O. Y. A. (2020). The role of leaders in management control. International Journal of Psychosocial Rehabilitation, 24(7), 8230-8238. https://doi.org/10.37200/IJPR/V24I7/PR27080 3

Ross, G. F. (2006). Tourism industry employee workstress - A present and future crisis. Journal of Travel and Tourism Marketing, 19(2-3), 133-147. https://doi.org/10.1300/J073v19n02_11

Saeed, I., Waseem, M., Sikander, S., \& Rizwan, M. (2014). The relationship of turnover intention with job satisfaction, job performance, leader member exchange, emotional intelligence and organizational commitment. International Journal of Learning and Development, 4(2). https://doi.org/10.5296/ijld.v4i2.6100

Sampson, W.-G., \& Akyeampong, O. (2014). Workrelated stress in hotels: An analysis of the causes and effects among frontline hotel employees in the Kumasi Metropolis, Ghana. Journal of Tourism \& Hospitality, 04(02). https://doi.org/10.4172/2167-0269.1000127

Schaufeli, W. B., \& Bakker, A. B. (2004). Job demands, job resources, and their relationship with burnout and engagement: A multi-sample study. Journal of Organizational Behavior, 25(3),

293-315. https://doi.org/10.1002/job.248

Schuler, R. S. (1980). Definition and conceptualization of stress in organizations. Organizational Behavior and Human
Performance, 25(2), 184-215. https://doi.org/10.1016/0030-5073(80)90063$\mathrm{X}$

Sewwandi, D. V. S., \& Perere, D. (2016). The impact of job stress on turnover intention: A study of reputed apparel firm in Sri Lanka. $3 r d$ International HRM Conference, 3(1), 223-229. Retrieved from http://journals.sjp.ac.lk/index.php/phrc/article/ view/2918/1958

Skelton, A. R., Nattress, D., \& Dwyer, R. J. (2019). Predicting manufacturing employee turnover intentions. Journal of Economics, Finance and Administrative Science. https://doi.org/10.1108/JEFAS-07-2018-0069

Tongco, M. D. C. (2007). Purposive sampling as a tool for informant selection. Ethnobotany Research and Applications, 5, 147-158. https://doi.org/10.17348/era.5.0.147-158

Truitt, D. L. (2011). Effect of training and development on employee attitude as it relates to training and work proficiency. SAGE Open, l(3), 1-13. https://doi.org/10.1177/2158244011433338

Vagg, P. R., \& Spielberger, C. D. (1998). Occupational stress: Measuring job pressure and organizational support in the workplace. Journal of Occupational Health Psychology, 3(4), 294-305. https://doi.org/10.1037/10768998.3.4.294

Verhofstadt, E., Baillien, E., Verhaest, D., \& De Witte, H. (2017). On the moderating role of years of work experience in the Job DemandControl model. Economic and Industrial Democracy, 38(2), 294-313. https://doi.org/10.1177/0143831X15569550

Xie, Z., Wang, A., \& Chen, B. (2011). Nurse burnout and its association with occupational stress in a cross-sectional study in Shanghai. Journal of Advanced Nursing, 67(7), 1537-1546. https://doi.org/10.1111/j.13652648.2010.05576.x

Zhang, G., \& Lee, G. (2010). The moderation effects of perceptions of organizational politics on the relationship between work stress and turnover intention: An empirical study about civilian in skeleton government of China. IBusiness, 02(03), 268-273. https://doi.org/10.4236/ib.2010.23034

Zikmund, W. G., Babin, B. J., Carr, J. C., \& Griffin, M. (2013). Business research methods (9th ed.). Mason: Cengage Learning Custom Publishing. 